\title{
Małgorzata Stawiak-Ososińska, Sztuka położnicza dla kobiet. Kształcenie akuszerek na ziemiach polskich w dobie niewoli narodowej (1773-1914), DIG, Warszawa 2019, ss. 551 (rec. B. Urbanek)
}

Położnictwo, jak przypomina Autorka recenzowanej pozycji, „,jest jedną z najstarszych dziedzin medycyny [...], należy do rzędu nauk stosowanych, łącząc wiedzę poznawczą z praktyką, wiążąc sprawności manualne z koniecznością posiadania wiedzy i odpowiednich dyspozycji psychicznych, uwiarygodnionych pozyska-

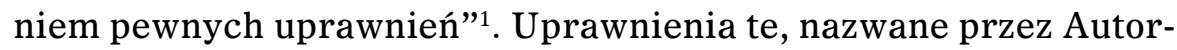
kę tzw. wykonawstwem, sprowadzać się miały jeszcze pierwotnie do pomocy udzielanej położnicy przez inną kobietę, doświadczoną „życiowo”, jak ją określano. Pomoc ta była też pojmowana jako jej uczestnictwo w tym niezwykłym akcie, jakim było i jest przyjście na świat nowego życia. Empatia, wsparcie były podstawą, najważniejszym elementem tego udziału, zanim stało się ono, z upływem wielu stuleci, prawdziwą profesją popartą fachowym przygotowaniem, w tym umiejętną obserwacją, wykonywaniem koniecznych rękoczynów.

Autorka, mimo że nie jest przedstawicielką tego zawodu, z prawdziwym znawstwem kreśli obraz kształtowania tej profesji, określając ją mianem „sztuki”, rozpoczynając od lat 70. XVIII stulecia aż po początek XX w., czyli czasy wyłaniania i rozwijania szkolnictwa położniczego na ziemiach polskich.

Publikacja pt. Sztuka położnicza... składa się z pięciu zasadniczych rozdziałów, nie licząc wstępu, zakończenia, bibliografii oraz siedmiu dołączonych do treści aneksów, indeksu osobowego, spisu tabel i ilustracji, ale także wykazu używanych skrótów.

Całość stanowi logiczny i sensownie przemyślany układ, oparty na zasadach problemowo-chronologicznych. Wstęp wprowadza w zagadnienie zarówno położnictwa, rozwijanego na ziemiach polskich

${ }^{1}$ M. Stawiak-Ososińska, Sztuka położnicza dla kobiet. Kształcenie akuszerek na ziemiach polskich w dobie niewoli narodowej (1773-1914), DIG, Warszawa 2019, s. 11. 
w XVIII w. aż do początków XX, a i samego tytułowego problemu: osób wykonujących obowiązki najpierw tzw. babki, wreszcie akuszer$\mathrm{ki}$, a zwłaszcza rodowodu kształcenia zawodowego w tej dziedzinie. Doktor M. Stawiak-Ososińska nie pomija przy tym ważnej kwestii wyjaśnienia pochodzenia samej nazwy rodzącej się w tym czasie profesji, sięgając do języka francuskiego: accoucher, skąd wywodzi się obowiązująca w literaturze medycznej XIX w. nazwa akuszerka. Autorka wskazuje przy tym na aktualny stan badań w opisywanej tematyce. Pokazuje dotychczasowe dokonania, a czyni to z ogromną dociekliwością, zwracając uwagę zarazem na nowe dostrzeżone, a uprzednio niezbadane problemy (m.in. szkół felczersko-położniczych, programów, systemów organizacji kształcenia, personelu nauczającego oraz uczennic ówczesnych instytucji położniczych).

Podkreślić przy tym należy wielość i różnorodność zgromadzonej przez Autorkę literatury, opracowań w tym przedmiocie zarówno polskich, jak i obcojęzycznych, m.in. rosyjskich, białoruskich, niemieckich, w tym materiałów źródłowych. Autorka dotarła bowiem do ośmiu archiwów, w tym sześciu spoza granic naszego kraju, tj. Rosyjskiego Państwowego Archiwum Historycznego w Sankt Petersburgu, Litewskiego Państwowego Archiwum Historycznego w Wilnie, Centralnego Państwowego Archiwum Historycznego Ukrainy we Lwowie, Państwowego Archiwum Obwodu Lwowskiego i Państwowego Archiwum Historycznego Białorusi w Grodnie oraz archiwum przy Szkole Medycznej Kamieniecko-Podolskiej. Prócz polskich zbiornic XVIII-XIX-wiecznych dokumentów zlokalizowanych w Warszawie (Archiwum Główne Akt Dawnych) czy Krakowie (Archiwum UJ, PAN i PAU) dokonała penetracji zasobów archiwalnych w Białymstoku, Bydgoszczy, Gdańsku, Lublinie, Łodzi oraz Poznaniu. Wspomnieć też warto o dziale rękopisów bibliotek, m.in. w Wilnie, do których dotarła. Autorka korzystała w podanych miejscach nie tylko z dokumentów (m.in. sprawozdań, listów, świadectw szkolnych czy aktów normatywnych), ale także starodruków, pamiętników, podręczników, prasy z XVIII, XIX i początków XX w. oraz wielu innych publikacji (w wykazie wymieniła blisko 120 pozycji). Ponadto posłużyła się także informacjami zawartymi w encyklopediach i słownikach.

Autorka zwróciła także uwagę na braki w dostępnym materiale źródłowym, zwłaszcza archiwów białoruskich. Pomimo wymienionych trudności w dotarciu do pewnych źródeł Autorka starała się spenetrować okres przeszło 140 lat (czyli od 1773 do 1914 r.), terytorium Polski także przed pierwszym rozbiorem. 
Jako cel swoich dociekań badawczych podała: ustalenie w podanym czasie lokalizacji ówczesnych szkół i wypełnienie istniejącej luki dotyczącej miejsca, nazwy i czasu funkcjonowania ośrodków kształcenia położnych. Ponadto jej zamierzeniem było poznanie zakresu i możliwości realizowanego procesu dydaktycznego w badanym czasie, w tym m.in. przez rozpoznanie zaplecza klinicznego istniejących szkół, a przede wszystkim opracowanie problemu funkcjonowania szkolnictwa zawodowego tej profesji na ziemiach polskich, co przy znacznym dotychczasowym rozproszeniu opracowań i braku całościowego ujęcia zagadnienia wydaje się słuszne i uzasadnione. Dodać nadto można, że zamierzenia dr Stawiak-Ososińskiej wyartykułowane we wstępie książki stanowią pewne novum badanej problematyki na temat położnictwa.

Zagadnienie szkolnictwa położniczego Autorka ukazała na tle ówczesnej sytuacji kraju, sposobów udzielanej pomocy medycznej w XVIII w., co niejako bardziej uwyraźniło potrzebę i działania zmierzające do poprawy stanu opieki nad kobietą rodzącą w wymienionym i kolejnym już stuleciu. Stąd w pierwszym rozdziale nazwanym Pomoc medyczna $w$ XVIII wieku rozpatrywała sytuację bytowo-sanitarną ówczesnego społeczeństwa, istniejące kadry medyczne, dostępne metody interwencji medycznej, uwzględniając obecne wtedy w praktyce położniczej obrzędy związane z porodem i połogiem, a często powiązane z magią, wierzeniami zresztą różnego pochodzenia. Przedstawiła jednak i próby czynione jeszcze w XVIII w. zmierzające do poprawy stanu opieki, m.in. przez rozwój edukacji, a wynikające, jak oceniła, m.in. z trendów płynących z Europy Zachodniej. W kolejnym, znacznie rozbudowanym rozdziale skupiła się na omówieniu Tworzenia i rozmieszczenia szkót położniczych na ziemiach polskich $\mathrm{w}$ okresie zmian wynikających z rozbiorów Polski dokonywanych przez Austrię, Rosję i Prusy. W jednym z pierwszych podrozdziałów powróciła jednak do sytuacji przed utratą niepodległości, opisując proces powstawania ośrodków kształcenia, szczególnie przy udziale Komisji Edukacji Narodowej i ówczesnych uniwersytetów. Dokonała przy tym oceny stanu i podejmowanych wtedy działań reformatorskich dotyczących uczelni krakowskiej czy wileńskiej. Skupiła się także na szkolnictwie, zakładanym z inicjatywy - jak określiła - ,postępowych arystokratów”. W dalszej kolejności omówiła szkoły akuszerek funkcjonujące w zaborze austriackim, zaborze rosyjskim (ziem zabranych). W ostatnim przypadku - zaboru rosyjskiego - uwzględniła podział na pierwszą połowę XIX w. i drugą połowę tego wieku, opisując szkoły, jak już za- 
znaczono, mniej dotąd znane - o profilu akuszersko-felczerskim. W zaborze pruskim pisała o szkolnictwie akuszerek zlokalizowanym w: Prusach Zachodnich, Południowych i Nowowschodnich. Oddzielnie ujęła zakłady kształcenia odnotowane po roku 1815 . W ostatnim podrozdziale rozdziału drugiego przedstawiła szkoły funkcjonujące w Księstwie Warszawskim, a następnie Królestwie Polskim. Tutaj skoncentrowała się na opisie następujących szkół: warszawskiej akuszerek i babek wiejskich, usytuowanych przy przytułkach położniczych i prywatnych. Tabelarycznie i na mapie w układzie zmieniających się granic ziem zaborowych ukazała lokalizacje zakładanych w latach 1773-1914 placówek oświatowych dla akuszerek. Wizualna prezentacja tych danych uzupełnia, a zarazem podkreśla walory treści książki². Jest też pewna, i to ciekawa forma podsumowania treści prezentowanego okresu: tworzenia położniczych instytucji na ziemiach polskich. W rozdziale III zatytułowanym Sytuacja materialna szkót akuszerskich $w$ XIX wieku i na poczatku XX w. Autorka koncentruje się na ukazaniu zaplecza klinicznego i dydaktycznego różnego rodzaju szkół o wspomnianym już profilu. Jeden $\mathrm{z}$ podrozdziałów $\mathrm{z}$ tej grupy poświęciła środkom i stosowanym wtedy pomocom dydaktycznym, ukazując na załączonych ilustracjach przykłady fantomu, modele rozwoju poszczególnych etapów ciąży ${ }^{3}$. W tej części (tab. 4) przytoczyła wykaz wykorzystywanych - wybranych - podręczników, a wydanych drukiem w latach 17741914? (aczkolwiek datą końcową tego zapisu winien być rok 1912, brak jest bowiem odnotowanych wydań po tym czasie - przynajmniej w podanej tabeli) ${ }^{4}$. Rozdział IV w swej treści uwzględnia Strukturę organizacyjna szkót akuszerskich $\mathrm{z}$ opisem funkcji dyrektora placówki, z omówieniem jego obowiązków administracyjnych i merytorycznych. Autorka posłużyła się w tym względzie rozporządzeniami, ustawami i regulaminami pochodzącymi z różnych zakładów oświatowych, przeznaczonych dla położnych. Zwróciła też uwagę na wszelkie zmiany zachodzące $\mathrm{w}$ zakresie obowiązków wynikających z pełnienia tych obowiązków. Za niezwykle cenne, a wymagające żmudnych poszukiwań, można uznać przytoczony przez Autorkę wykaz osobowy tej kierowniczej kadry (dyrektorów-profesorów) poszczególnych szkó1 $\mathrm{z}$ lat 1773-1914, zamieszczony $\mathrm{w}$ tab. $5^{5}$. W kolejnych podrozdziałach omówiła pozostały, merytoryczny personel placówek, a mianowicie zadania tzw. drugiego nauczyciela/asystenta i akuszerki zakładowej.

\footnotetext{
2 Tamże, s. 166-170.

3 Tamże, s. 234, 237.

4 Tamże, s. 242-243.

5 Tamże, s. 253-255.
} 
W tym przypadku podała listę akuszerek wraz okresem sprawowania przez nie tej funkcji w wyszczególnionych instytucjach (tab. 6) ${ }^{6}$. Niezwykle interesujący jest podrozdział zatytułowany Uczennice ${ }^{7}$, a w nim opis wymogów stawianych kandydatkom i wreszcie dokonana socjologiczna charakterystyka zbiorowości uczniowskiej - położnych drugiej połowy XVIII aż do początków XX w ${ }^{8}$. Autorka nie pominęła problemów, jakie występowały w procesie kształcenia tej zbiorowości, a związanych m.in. z naborem kandydatek, zwłaszcza ze środowiska wiejskiego. Kolejną omawianą częścią były podopieczne, tj. pacjentki ówczesnych uczennic-akuszerek, w tytule rozdziału określone jako „naukowy materiał” kliniczny 9 . Autorka poddała tu także krytycznej ocenie warunki praktycznego kształcenia akuszerek, ale i możliwości zwalczania, jak to określiła, „utrwalonych przez wieki stereotypów”10. W rozdziale V: Organizacja procesu dydaktycznego prezentuje: czas i wymiar kształcenia. W tym przypadku posłużyła się również tabelą do zilustrowania czasu trwania nauki (tab. 7) ${ }^{11}$, ukazując w sposób całościowy problem, i to z perspektywy wszystkich ośrodków, w których nauczano przyszłe akuszerki. Dalszą częścią tego rozdziału stało się omówienie sposobów i form kształcenia, różnicując je w zależności od lokalnych możliwości (również słuchaczek szkoły), ale i dostępu do pomocy naukowych. Zakres kształcenia teoretycznego w pierwszych latach istnienia (końca XVIII i pierwszej połowy XIX w.) ${ }^{12}$ podzieliła na trzy zagadnienia: a) wiadomości przekazywane uczennicom w pierwszych latach istnienia szkół (w podanym powyżej czasie), b) poszerzanie programu kształcenia o nowe treści, wprowadzane od lat 30. XIX w., c) zakres kształcenia w szkołach akuszerskich z klasami przygotowawczymi oraz w szkołach akuszersko-felczerskich. Zbiór treści w przypadku szkół akuszersko-felczerskich przedstawiono w tabeli, w formie zbiorczej (tab. 9) ${ }^{13}$. Jednak połączenie tych dwóch niejako systemów nauczania i pewne dokonane skróty w treści (?) spowodowały, że ta część wydaje się mniej klarowna. Bowiem obok analizy (treści czy realizowanego planu zajęć), którą wykorzystała Autorka ${ }^{14}$, brak jest pewnego podsumowania czy nawet pogłębionej oceny tych sys-

\footnotetext{
6 Tamże, s. 266-268.

7 Tamże, s. 269-308.

8 Tamże, s. 287.

9 Tamże, s. 308-322.

10 Tamże, s. 322.

11 Tamże, s. 327-330.

12 Tamże, s. 348.

13 Tamże, s. 369-370.

14 Tamże, s. 370-372.
} 
temów: wykazując różnice, ewentualne braki w ich funkcjonowaniu. Piąty rozdział kończy omówieniem zagadnienia pt. Egzaminowanie i dyplomowanie, dość szeroko zresztą ujętym. Autorka przedstawia bowiem nie tylko przebieg weryfikacji stopnia opanowanej wiedzy czy też procedurę samego aktu nadawania dyplomu, ale także zwyczaju wyposażania absolwentek przez szkołę w ważny atrybut ich przyszłej pracy (torbę położniczą), wiążąc je niejako emocjonalnie z miejscem uzyskanych kwalifikacji.

Zakończenie stanowi podsumowanie omówienia procesu rozwoju i ewolucji kształcenia akuszerek/położnych na naszych ziemiach od 1773 do 1914 r. Zwróciła tu uwagę na ich formy i liczbę powstających szkół, ocenioną jednak jako dość skromną. Ponadto Autorka poddała analizie zmieniający się poziom przyjmowanych kandydatek do szkó1 na przestrzeni tego okresu. Zreferowała społeczny stosunek do tego typu kształcenia na naszych ziemiach, który - jej zdaniem - dzięki niepochlebnej jego ocenie przez różne środowiska niejednokrotnie utrudniał rozwój zawodowy. Podkreśliła przy tym zaangażowanie twórców i organizatorów tego typu kształcenia, to im, jak zaznaczyła, „zawdzięczać należy” kontynuowanie nauczania w tej dziedzinie i zapewnienie systematycznej poprawy opieki nad położnicami.

Cennym uzupełnieniem książki są ilustracje, często unikatowe oraz aneksy. Warto przy tym zwrócić uwagę na samą okładkę książki, detal obrazu Loren Entza „The Midwife”, wprowadzający niejako „z ciepłym przesłaniem” w samą jej treść. Ponadto bogatą w źródła i opracowania bibliografię, o czym już wspominano. Książka autorstwa Małgorzaty Stawiak-Ososińskiej zasługuje z pewnością na uwagę i może być polecana przyszłym adeptom tej specjalności medycznej, chociaż nie tylko... Pozycja ta ma bowiem wiele walorów poznawczych, dotąd pomijanych w naszej historiografii. Autorka zaś włożyła ogromny trud w przygotowanie tej publikacji. 